8. Солдатенков О.В. Правове регулювання видатків на реалізацію конституційного права громадян на охорону здоров'я в Україні та країнах Центральної Європи : автореф. дис. ... докт. юрид. наук : 12.00.07 / Київський національний університет імені Тараса Шевченка. Київ, 2010. 47 с.

9. Лівак П.Є. Правове забезпечення фінансування охорони здоров’я в Україні : автореф. дис. ... канд. юрид. наук : 12.00.07 / Національний університет Державної податкової служби України. Київ, 2009. 18 с.

10. Гладун 3.С. Адміністративно-правове регулювання відносин у сфері охорони здоров'я за законодавством України. Вісник Наџіональної академії правових наук України. 2014. № 1 (76). C. $103-111$.

11. Руснак Л.М. Адміністративно-правове забезпечення права на охорону здоров'я в Україні: дис. ... канд. юрид. наук : 12.00.07 / Університет «Україна». Київ, 2016. 207 с.

12. Буткевич М.М. Досвід медичного страхування у зарубіжних країнах. Науковий вісник НЛТУ України. 2011. Вип. 21.10. С. 178-184.

13. Заруба О.Д. Страхова справа : підручник. Київ : Тов. «Знання», 1998. 321 с.

14. Коцюрубенко Г.М. Розвиток медичного страхування в Україні. Вісник соиіально-економічних досліджень. 2009. № 35. С. 217-222.

15. Гладун 3. Адміністративно-правове регулювання відносин у сфері охорони здоров'я населення. Міжнародні науково-практичні конференції за різними юридичними напрямками. 2006. URI: http://www.lex-line.com.ua/?language=ua\&go=full_article\&id=27 .

16. Шатковський Я.М. Стандартизація у системі обов'язкового медичного страхування в Україні (адміністративно-правовий аспект) : автореф. дис. ... канд. юрид. наук : 12.00.07 / Інститут законодавства Верховної Ради України. Київ, 2009. 20 с.

POMАНЕНКО М.B.

\title{
ОХОРОНА НАВКОЛИШНЬОГО ПРИРОДНОГО СЕРЕДОВИЩА ЯК ФУНКЦІЯ ОРГАНІВ МІСЦЕВОГО САМОВРЯДУВАННЯ
}

\begin{abstract}
У статті розглядається питання визначення повноважень органів місцевого самоврядування щодо збереження навколишнього природного середовища, з огляду на те що сьогодення України характеризується загрозливим станом довкілля нашої країни, який, у свою чергу, зобов'язує політиків, науковців і громадськість зосередити максимум уваги на екологічному аспекті суспільних процесів. Автор акцентує увагу на тому, що життєздатне навколишнє середовище здатне впливати на подальше існування нашого суспільства, тому суспільство, а також населення окремих територій має залучатися до формування дієздатних заходів щодо забезпечення екологічної безпеки. Саме місцевому населенню в більшому обсязі доступна інформація про реальну екологічну ситуацію на території його проживання. Дослідження діяльності органів місцевого самоврядування у збереженні довкілля і шляхів вирішення пов'язаних із цим проблем є актуальним безпосередньо в Україні. Автор доводить, що стан навколишнього середовища впливає не тільки на сьогоденний розвиток і можливості виходу з екологічної кризи, а й на загальне існування українського суспільства, оскільки нинішні негативні антропотехногенні навантаження на довкілля можуть призвести до незворотних наслідків. Місцевий рівень інституційної системи охорони навколишнього природного середовища включає органи місцевого самоврядування (рада, голова відповідної ради, виконавчі органи ради), місцеві державні адміністрації й територіальні підрозділи відповідних
\end{abstract}

(C РОМАНЕНКО М.В. - старший викладач кафедри правового забезпечення господарської діяльності (Харківський національний університет внутрішніх справ) 
центральних органів виконавчої влади. Також проаналізовано умови реалізації органами місцевого самоврядування державної політики у сфері охорони навколишнього природного середовища. Визначається, що сферу охорони навколишнього природного середовища варто вважати за предмет дослідження різних галузей науки. Актуальність зазначеної теми зумовлена наявним питанням сучасного стану законодавчого та нормативно-правового забезпечення управління екологічною сферою на місцевому рівні. Автор акцентує на тому, що державну політику у сфеpi охорони навколишнього природного середовища потрібно спрямувати на більш продуктивне сприяння сталому розвитку держави.

Ключові слова: державне управління, органи місцевого самоврядування, державна політика, охорона навколишнього природного середовища, екологічна галузь.

The article deals with the issue of determining the powers of local self-government bodies regarding the preservation of the natural environment, given that Ukraine's present is characterized by a threatening state of the environment of our country, which, in its turn, obliges politicians, scholars and the public to focus on the environmental aspect of social processes. The author focuses on the fact that a viable environment can influence the further existence of our society, therefore, society, and in the case of population of certain territories, should be involved in the formation of effective measures to ensure environmental safety. It is the local population that has more information about the real ecological situation on the territory of their residence. The article should be considered important because the research of the problems of local self-government in preserving the environment and ways of their solution, directly in Ukraine, and publications on the given topic is very small in the present state. In the article, the author argues that the state of the environment depends not only on the current development and the possibility of emerging from the environmental crisis, but the general existence of Ukrainian society in general, since the current negative anthropogenic environmental pressures can lead to irreversible consequences. The local level of the institutional system for the protection of the environment includes local governments (council, chairman of the relevant council, executive bodies of the council), local state administrations and territorial subdivisions of relevant central executive bodies. The article also provides an analysis of the conditions for the implementation of state policy in the field of environmental protection by local government bodies. The author determines that the scope of environmental protection should be considered as a subject of research various branches of science. The urgency of this topic is due to the existing issues of the current state of legislative and regulatory provision of management of the environmental sphere at the local level. The author emphasizes that the state policy in the field of environmental protection should be directed at the pain of productive promotion of sustainable development of the state.

Key words: public administration, local government, state policy, environmental protection, environmental sector.

Вступ. Для сучасної України характерним є забезпечення сталого природокористування й охорони навколишнього природного середовища як найбільш важливого завдання держави та суспільства. Складним $є$ те, що навіть у разі врахування багатьох питань з використання природних ресурсів у законодавчій і нормативній базі нашої країни ситуація навколо екологічного стану залишається складною.

Вивченням і дослідженням теоретико-методологічних засад державного регулювання екологічної політики на сучасному етапі займалися такі вітчизняні та зарубіжні вчені, як Г. Атаманчук, Б. Данилишина, В. Кравців, Н. Малиш, М. Пилипчук, М. Хилько й ін. Насамперед питання охорони навколишнього середовища як функції органів місцевого самоврядування розглядали такі українські вчені, як П. Біленчук, В. Вакуленко, Н. Нижник та ін. Роботи зазначених авторів відображають низку аспектів державного управління, стану реформування галузі охорони довкілля й рівня раціональності використання природних ресурсів. 
Постановка завдання. Метою статті є всебічне дослідження та аналіз умов реалізації органами місцевого самоврядування державної політики в сфері охорони природного навколишнього природного середовища.

Актуальність статті зумовлено тим, що навіть у разі неодноразового прийняття законів і постанов Верховною Радою та Кабінетом Міністрів України з питань охорони навколишнього природного середовища ці закони ставали мало дієвими за умови соціально-економічної й фінансової кризи в державі, а також відсутності узгодженості в діях органів, уповноважених на здійснення державної екологічної політики, серед яких й органи місцевого самоврядування.

Результати дослідження. Закон України «Про органи місцевого самоврядування» статтею 2 визначає поняття місцевого самоврядування, згідно 3 яким місцеве самоврядування в Україні - це гарантоване державою право та реальна здатність територіальної громади - жителів села чи добровільного об'єднання в сільську громаду жителів кількох сіл, селища, міста - самостійно або під відповідальність органів і посадових осіб місцевого самоврядування вирішувати питання місцевого значення в межах Конституції й законів України. Місцеве самоврядування здійснюється територіальними громадами сіл, селищ, міст як безпосередньо, так і через сільські, селищні, міські ради та їх виконавчі органи, а також через районні й обласні ради, які представляють спільні інтереси територіальних громад сіл, селищ, міст[2].

Місцевий рівень із погляду системи охорони навколишнього природного середовища представлено сільськими, селищними, міськими радами та їх виконавчими органами; районними й обласними радами, що представляють спільні інтереси територіальних громад сіл, селищ i міст; районними у містах радами та їх виконавчими органами місцевими адміністраціями й територіальними підрозділами відповідних центральних органів виконавчої влади, які наділені різними за статусом повноваженнями, що впливає на можливість забезпечення реалізації державної політики у сфері охорони навколишнього природного середовища в повному обсязі. До місцевого рівня інституційної системи охорони навколишнього природного середовища зараховано як органи місцевого самоврядування, тобто місцеві ради, сільські, селищні, міські, районні, серед яких сьогодні виділяють як окрему групу органи місцевого самоврядування - обласні ради, так і місцеві державні адміністрації як органи загальної компетенції, територіальні підрозділи відповідних органів виконавчої влади [2].

Найбільш важливу роль відіграють органи місцевого самоврядування та державні органи місцевої влади як такі, що витримують головне навантаження під час формування й реалізації екологічної політики держави.

Метою державної екологічної політики є досягнення доброго стану довкілля шляхом запровадження екосистемного підходу до всіх напрямів соціально-економічного розвитку України 3 метою забезпечення конституційного права кожного громадянина України на чисте й безпечне довкілля, упровадження збалансованого природокористування та збереження й відновлення природних екосистем [5]. Відповідно до Основної стратегії державної екологічної політики України до 2030 року, затвердженої Верховною Радою України, першопричинами екологічних проблем України $€$ підпорядкованість екологічних пріоритетів економічній доцільності; неврахування наслідків для довкілля в законодавчих і нормативно-правових актах; переважання ресурсо- та енергоємних галузей у структурі економіки зі здебільшого негативним впливом на довкілля, що значно посилюється через неврегульованість законодавства під час переходу до ринкових умов господарювання; фізичне та моральне зношення основних фондів у всіх галузях національної економіки; низький рівень розуміння в суспільстві пріоритетів збереження довкілля й переваг збалансованого (сталого) розвитку, недосконалість системи екологічної освіти та просвіти; незадовільний рівень дотримання природоохоронного законодавства й екологічних прав та обов'язків громадян; незадовільний контроль за дотриманням природоохоронного законодавства й незабезпечення невідворотності відповідальності за його порушення; недостатнє фінансування 3 державного та місцевих бюджетів природоохоронних заходів, фінансування таких заходів за залишковим принципом.

Доцільним буде окремо виділити неефективність системи державного управління у сфері охорони навколишнього природного середовища й регулювання використання природних ресурсів, зокрема неузгодженість дій центральних і місцевих органів виконавчої влади й органів місцевого самоврядування, а також незадовільний стан системи державного моніторингу навколишнього природного середовища.

Низка повноважень у галузі охорони навколишнього природного середовища, зазначених у частині 2 статті 143 Конституції України, належать районним та обласним радам, що є органами 
місцевого самоврядування. Вони є представниками спільних інтересів територіальних громад сіл, селищ і міст. Так, за статтею 143 Основного Закону України, районним та обласним радам надано можливість вирішення інших питань, що зараховані законом до їхньої компетенції, які виходять за межі колективних потреб і запитів однієї територіальної громади.

Безпосередні повноваження органів місцевого самоврядування щодо охорони навколишнього природного середовища визначено статтею 33 Закону України «Про місцеве самоврядування в Україні», яким до власних (самоврядних) повноважень органів місцевого самоврядування зараховано підготовку й унесення на розгляд ради пропозицій щодо встановлення ставки земельного податку, розмірів плати за користування природними ресурсами, вилучення (викупу), а також надання під забудову та для інших потреб земель, що перебувають у власності територіальних громад; визначення в установленому порядку розмірів відшкодувань підприємствами, установами й організаціями незалежно від форм власності за забруднення довкілля та інші екологічні збитки; установлення платежів за користування комунальними й санітарними мережами відповідних населених пунктів; підготовка й подання на затвердження ради проектів місцевих програм охорони довкілля, участь у підготовці загальнодержавних і регіональних програм охорони довкілля; підготовка та внесення на розгляд ради пропозицій щодо прийняття рішень про організацію територій та об'єктів природно-заповідного фонду місцевого значення й інших територій, що підлягають особливій охороні; унесення пропозицій до відповідних державних органів про оголошення природних та інших об'єктів, що мають екологічну, історичну, культурну або наукову цінність, пам'ятками природи, історії або культури, які охороняються законом, підготовка й унесення на розгляд ради пропозицій щодо прийняття рішень про оголошення в місцях масового розмноження та вирощування потомства дикими тваринами «сезону тиші» 3 обмеженням господарської діяльності й добуванням об'єктів тваринного світу тощо[2].

До делегованих повноважень належать здійснення контролю за додержанням земельного та природоохоронного законодавства, використанням та охороною земель, природних ресурсів загальнодержавного й місцевого значення, відтворенням лісів; координація діяльності місцевих органів земельних ресурсів; погодження клопотань про надання дозволу на спеціальне використання природних ресурсів загальнодержавного значення; ужиття необхідних заходів щодо ліквідації наслідків надзвичайних ситуацій відповідно до закону, інформування про них населення, залучення в установленому законом порядку до цих робіт підприємств, установ та організацій, а також населення; здійснення контролю за діяльністю суб'єктів підприємницької діяльності у сфері поводження з відходами тощо[2].

Закон України «Про охорону навколишнього природного середовища» у статті 19 також зараховує до компетенції органів місцевого самоврядування значну кількість повноважень у галузі охорони навколишнього природного середовища, серед яких - здійснення реалізації рішень відповідних рад; координування діяльності підприємств, установ та організацій, розташованих на території відповідно села, селища, міста, незалежно від форм власності й підпорядкування; організацію розроблення місцевих екологічних програм; затвердження з питань охорони навколишнього природного середовища для підприємств, установ та організацій лімітів використання природних ресурсів, лімітів скидів забруднюючих речовин у навколишнє природне середовище в межах, відповідно, села, селища, міста; організацію, збирання, переробку, утилізацію й захоронення відходів на своїй території; формування й використання місцевих фондів охорони навколишнього природного середовища в складі місцевих бюджетів; погодження поточних і перспективних планів роботи підприємств, установ та організацій з питань охорони навколишнього природного середовища й використання природних ресурсів; забезпечення систематичного та оперативного інформування населення, підприємств, установ, організацій і громадян про стан навколишнього природного середовища, захворюваності населення; організацію екологічної освіти й екологічного виховання громадян тощо [6]. Окрім цього, у частині 3 статті 2 Закону України «Про оцінку впливу на довкілля» визначено органи місцевого самоврядування суб'єктами оцінювання впливу на довкілля та надано їм повноваження й у цьому напрямі [7].

Найбільш об'єктивна та повна інформація про реальну екологічну ситуацію на території їх проживання доступна населенню, водночас саме населення певної території найбільш зацікавлено в безпечному існуванні та покращенні стану навколишнього природного середовища. Безпосередніми представниками територіальних громад є органи місцевого самоврядування сільські, селищні й міські ради. Найпоширеніша форма безпосередньої участі громадян у вирішенні питань місцевого значення - реалізація прав територіальних громад на проведення не рідше ніж один раз на рік громадських слухань, під час яких порушуються питання сплати за користування 
природними ресурсами, про реалізацію заходів щодо охорони довкілля й багато інших питань рівня місцевого самоврядування, під час обговорення яких існує можливість висвітлення реального стану довкілля, з'ясування актуальних проблем і завдань задля можливості ефективного зосередження на їх вирішенні [1, с. 158-166].

Доречно в роботі В. Тюн відокремлює принципи реалізації органами місцевого самоврядування державної політики у сфері охорони навколишнього природного середовища, а саме: пріоритетність світових і загальнонаціональних інтересів у галузі охорони довкілля й використання природних ресурсів, а також урахування інтересів регіонів, районів, міст, селищ і сіл; стимулювання зусиль територіальних громад щодо забезпечення власного екологобезпечного розвитку, передбачає систему стимулів і заохочень громад здійснювати ефективну екологічну політику, забезпечувати плідну співпрацю із суб'єктами господарювання, громадськістю задля досягнення спільної мети - сталого розвитку охорони навколишнього природного середовища; пріоритетність новітніх технологій у господарській та іншій діяльності; відповідальність держави й керівників державних органів влади за вплив на розвиток країни та екологічну ситуацію в містах; обов'язковість додержання екологічних законів гармонізації співіснування людини, суспільства та природи; поєднання екологічного, соціального й економічного складників у ході здійснення господарської, інноваційної та іншої діяльності; упровадження ресурсозберігаючих, екологічно безпечних, маловідходних і безвідходних технологій у галузі економіки міст [3, с. 234].

Висновки. Підсумовуючи, варто наголосити на тому, що принципи державного управління процесами охорони навколишнього природного середовища сталого розвитку, крім принципів державної екологічної політики, мають включати також принципи іiі реалізації. Ці принципи мають визначати зміст екологічної політики на місцях, адже саме місцева влада найповніше може врахувати екологічні інтереси населення відповідної території.

Отже, можна резюмувати, що для підвищення ефективності роботи органів місцевого самоврядування у сфері екологічної політики України необхідно більш чітко визначити функції й повноваження органів місцевого самоврядування та їх відповідальність за прийняття рішення, адже саме рішучі дії в цьому напрямі поєднані з узгодженням нормативно-правових актів в екологічній галузі на місцевому, регіональному та державному рівнях матимуть вагоме значення у вирішенні питань охорони навколишнього середовища на загальнодержавному рівні.

\section{Список використаних джерел:}

1.Медведєва М. Проблема ефективності міжнародно-правових норм у галузі охорони навколишнього середовища. Публічне право. 2017. № 4. С. 158-166.

2.Про місцеве самоврядування в Україні : Закон України. Відомості Верховної Ради України (ВВР). 1997. № 24. Ст. 170

3.Світова програма дій Порядок денний на XXI століття. URL: https:// uk.wikipedia.org.

4.Тюн В.М. Адміністративно-правові засади наглядової діяльності правоохоронних органів України у сфері охорони природи : дис. ... канд. юрид. наук : 12.00.07. Львів, 2016. 234 с.

5.Про Основні засади (стратегію) державної екологічної політики України на період до 2030 року : Закон України від 28 лютого 2019 № 2697-VIII. URL: https://zakon.rada.gov.ua/laws/ show/2697-19.

6.Про охорону навколишнього природного середовища : Закон України. Відомості Верховної Ради України (ВВР). 1991. № 41. Ст. 546.

7.Про оцінку впливу на довкілля : Закон України. Відомості Верховної Ради Украӥни (BВP). 2017. № 29. Ст. 315. 